\title{
Ольга Мазепина
}

\section{4 ПРЕЛЮДИИ ДЛЯ ФОРТЕПИАНО К.М. ЛАКИНА}

\begin{abstract}
В статье подробно рассматривается цикл современного томского композитора К.М. Лакина «24 прелюдии для фортепиано». Изучается ряд аспектов произведения, актуальных для пианиста-исполнителя. При этом следует знать, что одним из первых исполнителей этого цикла является автор статьи. Отдельно изучается каждая пьеса, с точки зрения технических трудностей для молодого пианиста и с точки зрения целостности образного ряда.
\end{abstract}

Ключевые слова: томский композитор, цикл фортепианных пьес, Лакин, техника, образный ряд.

Имя современного томского композитора Лакина Константина Михайловича широко известно не только в музыкальном мире Томска и Томской области, но и далеко за пределами. Первый на томской земле член Союза композиторов России, Заслуженный работник культуры РФ, кавалер Ордена Дружбы народов, чье имя занесено в Книгу Почета Сибири за творческий и педагогический вклад в современное музыкальное искусство, Константин Михайлович и сегодня полон творческих идей. 20 января 2020 г. музыкальная общественность Томска отмечала 80-летие К.М. Лакина. Сочинения композитора включают симфонии, концерты, квартеты, трио, произведения для симфонического оркестра и ансамбля скрипачей, песни и романсы. Исследователи, музыковеды творчества К.М. Лакина отмечают романтические тенденции в его творчестве. Красота природы, глубина человеческих чувств, лирическое восприятие окружающего мира, почитание традиций мастеров классического прошлого - все это питает воображение композитора. Вместе с тем его сочинения звучат по-современному. К.М. Лакин экспериментирует, сочетая классические принципы с модернисткими, «авангардисткими». Он свободно оперирует стилями, 
обращаясь то к классическому, то к романтическому, то к современному.

Автор данной статьи соприкасалась с вокальным творчеством Константина Михайловича как концертмейстер, в течение многих лет работая с певцами - профессионалами и любителями. Позднее Константин Михайлович доверил мне исполнение своих некоторых фортепианных миниатюр, в том числе цикл «24 прелюдии для фортепиано». Процесс исполнительского постижения раскрыл много интересного в этой музыке, что побудило меня поделиться субъективными впечатлениями и мыслями.

Прелюдии создавались К.М. Лакиным на протяжении двух лет: 2016-2017 гг. И сразу же Областной «Дом искусств» выпустил сборник тиражом всего 55 экземпляров. 12 декабря 2018 г. в Хрустальном зале Томского музыкального колледжа имени Э.В. Денисова состоялась исполнительская презентация цикла. В предисловии к прелюдиям Константин Михайлович дает краткую характеристику жанра, их содержания и адресует их целевому исполнителю. Приведу целиком краткое предисловие композитора: «Прелюдия» - это «предигра» - вступление к чему-либо. Но начиная с Шопена, прелюдии становятся самостоятельными пьесамиминиатюрами. Прелюдии (их 24) чаще всего располагаются по «квинтовому кругу». Мы знаем прелюдии Шопена, Скрябина, Лядова, Рахманинова, Шостаковича. Рискнул и я создать этот цикл. Прелюдии имеют разное содержание - есть прелюдии игривые, печальные, торжественные, драматические, даже трагические. Я предполагаю, что большинство из них будет исполняться силами учащихся колледжей, а часть из них можно исполнить детьми детских музыкальных школ».

«24 прелюдии для фортепиано» К.М. Лакина - своеобразный «кладезь премудростей» романтического и современного фортепианного искусства, - прекрасный материал для учебного репертуара. Художественное исполнение этих разнохарактерных, современных пьес-миниатюр требует настоящего профессионального мастерства. Константин Михайлович удивительный человек. Он не просто наделен огромным талантом музыканта и композитора от природы. Неуемный романтик, он увлекался литературным сочинительством: писал стихи, фантастические рассказы, сюжеты которых, как сам говорил, видел во сне. Прочтение рассказов и стихов еще глубже 
позволило понять характер этого Человека, а вместе с ними и его музыку. Стихотворные строки к каждой из прелюдий К.М. Лакина - большая ценность, поэзия всегда является источником мощных рефлексий. Они подкупают своею искренностью, являются своеобразными внутренними настроями для исполнителя, будят воображение, помогают понять содержание и настроение, а значит, «включиться» эмоционально-психологически. А эмоциональный и содержательный строй прелюдий К.М. Лакина чрезвычайно многообразен. Его музыкальный язык наделен неожиданными поворотами в музыкальном развитии, по-современному звучащими диссонансами, моментами гармонической полифункциональности, переливами натуральных ладов. Ближайший коллега композитора, преподаватель ТМК Н.И. Ширяева, так охарактеризовала музыкальный стиль композитора в своей первой популярной монографии о нем: «...характерные «лакинские» черты стиля: это, прежде всего, синтез философской углубленности и «смакование» красочности гармоний, это «тихий» восторг от красоты «пейзажных» образов и зловещее звучание «роковых» мотивов, это сочетание русского колорита и европейских приемов музыкального развития». Кроме того, Ширяева отмечает склонность композитора к меланхолическим образам, отсутствие банальности, «избитых» интонаций. Самобытность, поэтическое воплощение природы в музыке, национальный колорит, внутренняя динамика музыки у Лакина во всем: в красоте гармонии, где неожиданные отклонения, нонаккорды, эллипсисы, доминантовые аккорды «с секстой», политональные структуры и полифункциональные, диссонирующие созвучия, как «авангардисткие» средства выразительности.

В рамках небольшой статьи попытаюсь сделать краткий обзор цикла прелюдий К.М. Лакина с его стихотворными вставками.

Первая прелюдия До мажор - это своеобразный пролог к циклу.

«Я грежу волшебным июнем, / Июнь - это лучший месяц,

Он самый светлый, счастливый, / Он самый лучший месяц»

Светлая миниатюра повествовательного характера с мелодией широкого дыхания в благостном до мажоре. Отклонения (ля и ми минор) создают колорит светло-грустного очарования. В данной фактуре ученику-пианисту необходимо не только агогически простроить мелодическую линию, но и сконцентрироваться на колоритно-обертоновой атмосфере звучания: осмыслить все слои фак- 
туры тембрально-полифонически, воссоздавая ее посредством артикуляции, динамики и красочной педализации.

Меланхолическое настроение прелюдии № 2 ля минор выражено средствами минорного лада, монотонно покачивающейся трехдольностью, пустотами квинт, ниспадающими, никнущими мотивами. Но особенно, хрупкостью гармоний широкого расположения в нонаккордовых созвучиях. На таком диссонирующем акустическом фоне рисуется картинка тоскливого настроения от холодного, мелкого дождя в осенний день. Обилие нон, тритонов «скребет душу». «Смутный сон, мою тоску развей, / Свистом, шорохом снежных хлопьев / Закружи, умчи в далекий отзвук / Несбывшегося...»/ Есть неожиданности: появление «темноватого» аккорда фригийского колорита в 15-м такте (пониженная вторая ступень - сибемоль).

«Утреннее пробуждение» - так можно охарактеризовать музыкальную зарисовку прелюдии № 3 соль мажор. «Светлое Утро настало - / С солнцем и птичьим пеньем, / С белыми облаками, /Чтобы вы тоже пели / Сердцем и душою, / Пели бесцельно, как птицы...». «Солнечная» тональность Соль мажор символически «изображает» первые лучи восходящего солнца, нисходящие мотивы - пение и перекличку утренних петухов. Юным пианистам в 1-м и 3-м, 18-м и 20-м тактах целесообразно нисходящий мотив исполнять левой рукой. В прелюдии № 4 ми минор удивительно нежные и ласковые интонации мелодии широкого дыхания окрашены русским колоритом. «...ты, песня-кристаллик, / Вспорхнешь и облачком летним / Все выше вдаль понесешься, / И скажут, следя за тобою: / «Вот облачко, с песнею схоже...». Полны выразительности и чудесной красоты тональные отклонения, секвенции, натуральные лады (фригийский - такты 21-25 с пониженной II ступенью), двойная доминанта 28-го такта, плавно переходящая во фригийское мелодическое трезвучие, каноническая имитация. Ученику-пианисту можно предложить инструментовать голоса, создавая каждому индивидуальную тембровую окраску. Характер прелюдии № 5 Ре мажор шуточный, игривый и, пожалуй, это самая «детская» пьеса в цикле. / «...Люди! / Вы ведь всегда лишь дети, / Вы ведь во всем - только дети! / Не странно ли слышать вам это, / Дети, забывшие детство?». В ритмике есть явное сходство с шуточной детской пляской, с притопами, прихлопами и т.п. Темп Andantino, обо- 
значенный композитором, по своим характеристикам близок allegretto, т.е. оживленный, игривый. Во всех танцевальных пьесах важно правильное ощущение метрических долей. Здесь же важно почувствовать «притоп» на слабой второй доле, которую композитор обозначает tenuno(-). Педагогу очень важно раскрыть ученику красоту гармоний композитора и тщательно проработать авторские штрихи.

Особая трогательность, доверительность, переживание присущи мелодическим интонациям прелюдии № 6 си минор, двухчастной по форме. Ее можно представить как соло для виолончели и фортепиано. / «Вы притаились, люди. / Где-то в душе глубоко, / У каждого еле слышно / В вас сожаленье плачет». По своему содержанию и меланхолическому настроению перекликается с прелюдией Шопена си минор. Но в отличие от западноевропейской шопеновской, в прелюдии К.М. Лакина основой является русский колорит.

Живая, светлая, «журчащая», как ручеек, музыка ля-мажорной прелюдии № 7 написана в вальсообразном движении. / «Есть на свете озеро, / Озеро лесное. / Из него ручей бежит / Тихой светлой струйкой». В ней игра света и тени. Теневые настроения присущи средней части. Музыка К.М. Лакина изобилует колоритом натуральных ладов, придающих особую «русскость» окраске звучания. Можно указать их ряд и в этой прелюдии в тактах 17, 26, 30, 38. Задачами исполнения являются: проработка мотивной структуры партии правой руки, где первые два такта представляют цельный восходяще-нисходящий мотив, в третьем и четвертом тактах происходит дробление, т.е. схема такая: $2+1+1$. Очень важен правильный, удобный выбор аппликатуры, позволяющий справляться с довольно сложной технически партией правой руки.

Прелюдия № 8 фа-диез минор представляет собой очень маленькую пьесу (24 такта) с печальными вздохами парных лиг в размере 6/8. «На землю падает снег. / Усталость. / Она всегда со мной...» / Навыки и средства «переживания» содержания этой прелюдии: выразительные цезуры, rubato, микроагогика, микродинамика, звуковой баланс, позволят выявить подлинную музыкальность исполнителя. Самая «авангардисткая», по выражению композитора, прелюдия № 9 ми мажор. Диссонансы больших септим и полигармонических созвучий «рисуют» таинственнофантастические образы. / «Привет вам, снежные вершины! / Свер- 
кающие гор алмазы! / Слепящая глаза - мои глаза живые, / Хрустальная громада льдов! / Как я хотел бы превратиться/ Во льдину, что плывет весною /Большой водою по реке...»/ Очень интересна вторая часть, где неожиданный поворот связан с затаенным появлением неизвестного, «пугающего» образа (с такта 23), наполненного диссонансной гармонией с обилием тритонов, септим, увеличенных трезвучий, септаккордов и вдруг - «просветленный» ми мажор в конце. Роль педали в создании обертоновой акустической атмосферы здесь велика, особенно во второй части, где педаль удерживается на протяжении трех тактов (такты 28-30). Очень важно правильно «смонтировать» звуковую вертикаль тембрально, придав более острый и светлый колорит верхнему голосу, приглушенность и, в то же время, глубину басу.

Упоительна по красоте музыка прелюдии № 10 до-диез минор, одной из самых чувственных в этом сборнике. / «Я пришел из светлой дали, / Где весной / Ивы почки распускали / Над водой. / В глубине небесный ветер / Завывал, / Гордый ястреб свои крылья /Раскрывал. / Я принес в душе свободной / Мир простой. / Он сиял во мне холодной чистотой... / И приснился сон мне странный: / Между скал / В сером небе из металла / Пик стоял / На вершине того пика / Был кристалл, / И в лучах багровых жарко /Он сверкал. / Вверх! К нему меня тянуло. / Я полез / По стальной горе с другими /До небес... / К прежней жизни возвратился / Я опять, / Но зачем-то стал я часто / Тосковать». Пьеса лирического содержания, глубокого размышления, имеет полифоническое развитие. Перекликается по романтическому настроению с прелюдий № 6. Но в отличие от «виолончельного соло» шестой прелюдии, здесь «инструментовку» можно представить как дуэт виолончели и скрипки. Пианист, особенно юный, должен ясно представлять и слышать тембры этих инструментов, уметь имитировать их на фортепиано средствами артикуляции и динамики. Исполнительские задачи связаны с навыками игры кантилены и полифонической дифференциации фактуры.

Прелюдия № 11 си мажор - это миниатюра с чертами хоральности. Первые две четырехтактные фразы строятся по принципу вопроса и ответа в мелодии верхнего голоса. / «Ты пройдешь сквозь время, / И остановится круг, / И ярче засветятся звезды / На бледносинем небе - / Это рассеется мгла / Перед зарею Утра» /. Неожиданное сопоставление гармоний в 9-м такте привносит контраст. 
Ля-бекар в басу (миксолидийский лад) уводит в отдаленные гармонические сферы с просветлением в такте 12 и архаичным колоритом плагального оборота (такты 15-16). Думаю, «главное слово» в этом фрагменте следует предоставить среднему голосу (ми-фа-ля бемоль-соль), как образному символу круга-креста, подобно баховской символике.

Шарманочный мотив прелюдии № 12 соль диез минор становится основой этой меланхолической пьесы, трехчастной по форме. / «Я куда-то иду без дороги, без света, / Без желанья себя уберечь от беды, / Забывая дожди, что не выпали летом, / Когда поле просило воды, / Забывая, что встретиться с парусом алым / Можно вдруг, вдалеке от морей и от рек. / Я, как путник в ночи, бесконечно усталый, / Без надежды и прав на ночлег...» / Печальная, чистая, спокойная, «осенняя» песня как бы покачивается на триольном аккомпанементе.

Прелюдия № 13 Фа-диез мажор представляет собой воздушную арабеску с ощущением «легкого ветерка» в мелодикогармонических фигурациях, играющего на поверхности воды. Импрессионистическая зыбкость, игра света и тени в ладовых переливах средней части, эллиптический оборот (такты 23-24), создают колорит, наполненный умиротворенностью, подобный светлому, прозрачному сну. / «На тихую воду шары голубые спустились / И тихо стонали, и пели мне что-то, живые» (Эфемериды) / Пианисту важно почувствовать легкие, падающие, «воздушные» пальцы с очень чуткими кончиками в технике leggiero. Партия левой руки «рисует» гармонический фон, окрашенный педалью.

Тревожный и драматический характер прелюдии № 14 мибемоль минор, как тяжелое «предгрозовое» состояние, композитор передает обилием диссонансов, стонущими сползающими секундовыми мотивами верхнего голоса. Восходящие мотивы (такты 5 и 7), подобно порывам ветра, рождают волю, настойчивость к преодолению. «Мучительно страшно и жутко, и грозно / Тоскливое тянется время... / Я холодом скован, глаза мои стынут / И серое небо висит, издеваясь, / И стонет, как прежде усталое сердце...»/ Ученику очень важно понять фразировку: четырехтактные фразы, по два мотива в каждой. Интонирование мелодии верхнего голоса позволит почувствовать нить напряжения. 
Прелюдию № 15 ре-бемоль мажор отличает острота фактуры, оживленный темп. Игривый, даже эксцентричный характер позволяет говорить о чертах скерцозности. Лишь в средней части «жалобный характер» лиг, и «обиженных» тритонов (такты 37-40) передают другое эмоциональное состояние, которое скоро опять сменяется скерцозностью. «...Услышал я трепет, увидел я горы / И солнце над ними... / И солнце согрелось улыбкой! / Что это такое? Насмешка? / Иль бред мой последний?.. / Ко мне приближалось, меня ослепило, /Во мне засияло - и солнце согрело... / Услышал я голос, зовущий из дали... / Я встал и, как прежде, наивный и сильный, / Пошел я туда, куда звало и крепло...» /. Исполнительские задачи связаны с тщательной проработкой штрихов и осмысления их характерности.

Ностальгия, печаль, размышление определяют настроение прелюдии № 16 си-бемоль минор. / «...И свежесть иллюзий навеки хранило /Слепое, как волны, седое, как пена, /Любви далекое слово» / Сама трактовка «мягкой» тональности си-бемоль минор еще со времен барокко имела печальный смысл. К тому же, обилие пустых квинт в мелодии, октав, секст, тритоновых и секундовых интонаций, сообщают остроту и напряжение, связанных с грустьютоской. Средняя часть в параллельном ре-бемоль мажоре (Росо ріu mosso) привносит нотку тепла, ассоциирующуюся со светлыми воспоминаниями, к примеру, воспоминание Наташи Ростовой о своем первом бале. Трепетность и иллюзорность ощутима в диссонансных созвучиях 26-го и 28-го тактов.

Весенние образы прелюдии № 17 Ля-бемоль мажор: журчание ручьев, птичий щебет, игра солнца вызывают ассоциации с целым рядом музыкальных пьес. Например, прелюдия Рахманинова Соль мажор, ор. 32, его романс «Весенние воды», романс Власова «Фонтану бахчисарайского дворца», «Арабеска» ми мажор Дебюсси и др. / «Струится, льется тихий свет, / Свет перемен, свет перемен» / Очень поэтичная, утонченная, восторженная, и в то же время изящная по характеру музыка прелюдии, потребует от исполнителя виртуозности, пассажной легкости, гибкой динамической филировки звука, умения дифференцировать фактуру. Характер прелюдии № 18 фа минор драматичный, динамика контрастная, кульминация до FF (такт 14) со спадом до ріапо. Ассоциации уводят к прелюдии до минор Ф. Шопена. 
«Поток весенний похож на Осень, / Он грозен, бурный ночной поток.

Я это знаю, но верю в чудо: / От сердца к сердцу прольется ток,

Ток алой крови и белых лилий, / Они пленяют и навсегда...» / Аккордовая фактура музыки ставит перед пианистом задачи динамического и артикуляционного выявления многослойности линий и тембров для создания объемности звучания фактуры. Это всегда непростая задача, особенно для юных пианистов.

Отголоски сентиментального вальса слышатся в чувствительной, душевной мелодии прелюдии № 19 ми-бемоль мажор. Задумчивое, грустно-мечтательное настроение свойственно жанру элегии.

«...Я долго-долго странствовал, / И позабылось многое, / Что было мне так дорого, / Когда я дома жил... / Но хмурым ветромхолодом / Однажды вдруг повеяло, / И вспомнил я о Севере / И о печальных кустиках, / О том, что было дорого, / И снова возвращается / В холодную, усталую, / Измученную грудь. / И грустно вдруг мне сделалось, / И я подумал: «Кустики, / Далекие и старые, / Я снова к вам вернусь!»/И вот я дома. Солнышко / Все так же освещает их, / И листики колышутся / На злом ветру опять. / «Сирень» - сказал я - «милая, / Сирень моя прекрасная, / Сирень, как я, несчастная, / Я так люблю тебя!» / Стихотворение К.М. Лакина «Северная сирень», на мой взгляд, созвучно содержанию этой прелюдии. Ассоциации уводят к рахманиновской «Сирени». Исполнительские задачи пианиста связаны с умением «петь на фортепиано», т.е. с кантиленой.

Характер прелюдии № 20 до-минор довольно озорной, полон неожиданных поворотов в развитии. Скерцозное обыгрывание нарочито наивных тем в сменяющихся регистрах, темп allegro, молниеносная смена динамики, неожиданные «обрывы» в паузы требуют от пианиста не только реактивности, но фантазии и воображения. / «Стремиться, мчаться мыслью вдаль, / В хрустальный мир, где все горит, / Где плавится в огнях металл, / Цепь алых лепестков дрожит...». В техническом отношении пьеса довольна сложна. Проработка штрихов, особенно парной лиги и двойных нот, потребует легких, острых, цепких пальцев. Маршеобразная прелюдия № 21 Си-бемоль мажор, исполненная энергии и юношеской восторженности, звучит оптимистично, в стиле марша-гимна. 
/ «Все это вашей Судьбою / Каждому в сердце стучится, / Каждому в память впадает» / Яркому, динамичному маршу приданы гротескные очертания с обилием диссонансов и яркой динамикой. По характеру перекликается с музыкой С.С. Прокофьва, с 7-м номером «Строители» из вокального цикла «Поэтическое настроение» самого Лакина К.М., на стихи Г. Лонгфелло. Специфика жанра марша ставит перед исполнителем задачи, которые на первый взгляд являются элементарными: передать бодрый маршевый характер, добиться чеканного ритма, остроты стаккато в аккордах, «фанфарности» интонаций с четкой артикуляцией в мелодии левой руки.

Прелюдия № 22 соль минор по характеру изящная, утонченная, мечтательная, жанр которой можно определить, как «что-то вроде вальса». "...Я грежу волшебным Июнем, / Грежу, засыпая...» / Написана в свободной импровизационной манере, в характере capriccioso, что свойственно русской музыке, особенно Чайковскомy. В средней части пьесы (piu mosso) уловимы отголоски «Подснежника» из «Времен года».

В моторно-двигательном отношении прелюдия № 23 фа мажор является одной из самых сложных в цикле. Она токкатного типа. Скоростная природа этого жанра потребует от пианиста «блестящих» легких пальцев, отменной артикуляции, цепких и звонких кончиков пальцев, непринужденных бросков и ловких кистевых жестов. / «Чистый, белый, смелый, / Ты мчишься, на льду скользя, / Ты крутишь ногой, а звезды / Висят и поют. Смейся!» / В маленькой пьесе изобилие технических трудностей: скачки, большое количество двойных нот, позиционных форм. Отличные ритмические способности, ловкость, двигательная автоматика- и все на динамике форте - это серьезный психологический ориентир, потому что состояние постоянного движения, без передышки, должно воспитать выдержку, волю «прийти к финишу». Мятущаяся сущность образа выражена в эффекте повторения мелодического ядра в упругом беге стаккатных терций.

Для пианиста прелюдия № 24 ре минор является самой сложной в психологическом отношении. Она трагична по своему содержанию. Перед исполнителем стоит довольно непростая задача - почувствовать и попытаться раскрыть бесконечную глубину смыслов через образно-интонационную многомерность сочинения.

«На землю падает снег. / Усталость. 
На землю падает снег. / Я вспомнил не этот снег.

Я вспомнил другую усталость, / Я вспомнил - от синих туманных зорь,

От жарких и знойных дней, / От теплой капели с крыш весной,

От вьюжистой злой метели - / Усталость - море огней и лиц,

И темные мачты гор, / И стаи огромных белых птиц,

Парящих в вышине... / На землю падает снег.

Усталость. / Она всегда со мной,

Усталость мне слышится в шуме елей, / И жалок весенний смех.

На землю падает снег. / Усталость...

«Смысловые события» пьесы делают непредсказуемой и динамичной развитие самой фактуры. При этом она остается естественной и удобной для пианиста, но только при условии долгого привыкания к ее неожиданностям, поворотам, изгибам. Но самая большая сложность - в акустическом воплощении ее пластов. Триольная пульсация на «ля» подобна нерву, проходящему сквозь всю ткань пьесы. На этот «нерв» нанизывается ниспадающий мотив «усталости» (такты 2, 4). В такте 15-м появляется новый мотив в партии правой руки, который противостоит мотиву «усталости». Возникает противоборство (такты 17-18). Этот фрагмент насыщенными, кластерными гармоническими красками сходен по смыслу с партией фортепиано Г. Свиридова «Отчалившая Русь» из одноименного вокального цикла на стихи С. Есенина. Жесткие диссонансы, упрямые акцентированные триоли, синкопированная октава «фа», регистровый взлет, окрашенный единой педальной звучностью, создают очень тревожное акустическое пространство, внезапно обрывающееся, подобно выстрелу, на фермате. Кульминация достигает высшего накала $(F F)$ на взволнованном, стремительно восходящем потоке стаккатированных триолей и дуолей в диапазоне пяти октав. Ее спад подобен преодолению противоборства и «обескрыленности» на фермате (такты 23, 24). Доминантовый предыкт, - динамически филируемое «ля» на протяжении четырех тактов перед возвращением основной тональности и «мотива усталости», - воспринимается как момент некой истины, ощущаемой в третьей части прелюдии (TempoI) как внутреннее смирение. Возвращение первоначального мотива, преобразование темы кульминации из стремительной, взволнованной в просветленную, легкую, как дымка, растворяющейся в выси, воспринимается как смирение. 
В тактах 42-44 в аккордах доминанты и тоники ре минора слышится «роковой» оттенок. Все заканчивается одинокой тоникой «ре» контроктавы.

В рамках одной статьи невозможно охватить все многообразие проблем, возникающих в связи с циклом «24 прелюдии для фортепиано» К.М. Лакина. Процесс исполнительского прочтения пьес замечательного томского композитора, члена Союза композиторов России, бесконечен и не исчерпывается прохождением отдельных пьес. Формы творческой работы могут быть самыми разными. Например, концертное исполнение цикла целиком силами группы учащихся-пианистов. Он может перемежаться стихотворными «вставками», раскрывающими содержание пьесы и т.п.

Творческая работа над прелюдиями К.М. Лакина требует от педагога огромной душевной отдачи, неустанного стремления к новым знаниям, напряженного интонационного вслушивания, постоянного обогащения слухового опыта. Эти интеллектуальные и эмоциональные затраты энергии окупаются художественным наслаждением и сознанием приобщения ученика к миру духовных ценностей отечественной культуры.

\section{Использованные источники}

1. Лакин К.М. 24 прелюдии для фортепиано. Томск : Дом искусств, 2017.

2. Ширяева Н.И. «Дело всей его жизни». Томск : Изд-во Томского ЦНТИ, 2013.

3. Рыбакова Ж., Лакин К., Бакалдин Г. Семейный альбом. Томск, 2018.

4. Лакин К.М. «Поэтическое настроение». Цикл романсов на стихи Г. Лонгфелло для баритона и фортепиано. Казань, 1965; Томск : Изд-во научно-технической литературы, 2004.

5. Будников В.В. Тембральная монтировка-маскировка звуков в фортепианной фактуре: синтетический аспект // Музыкальный альманах Томского государственного университета. 2020. № 9.

6. Нейгауз Г.Г. Об искусстве фортепианной игры. М., 1961.

\section{Olga Mazepina}

\section{PRELUDES FOR PIANO BY K. LAKIN}

Musical almanac of Tomsk State University, 2020, no. 10, pp. 80-92. doi: $0.17223 / 26188929 / 10 / 8$

The article discusses in detail the cycle of the contemporary Tomsk composer K. Lakin "24 Preludes for piano". A number of aspects of the composition that are relevant for the pianist-performer are considered. At the same time, you should 
know that one of the first performers of this cycle was the author of the article. Each piece has been studied separately, from the perspective of technical difficulties for a young pianist and from the point of view of the integrity of the figurative series.

Keywords: Tomsk composer, cycle of piano pieces, Lakin, technique, figurative series.

\section{The used sources}

1. Lakin K.M. 24 prelyudii dlya fortepiano. [24 preludes for piano] Tomsk, OGAUK «Dom iskusstv», 2017;

2. SHiryaeva N.I. «Delo vsej ego zhizni». ["The work of his whole life."] Tomsk: Izd-vo Tomskogo CNTI, 2013;

3. Rybakova ZH., Lakin K., Bakaldin G. «Semejnyj al'bom». ["Family Album"] - Tomsk,2018;

4. Lakin K.M. «Poeticheskoe nastroenie» Cikl romansov na stihi G. Longfello dlya baritona $\mathrm{i}$ fortepiano. ["Poetic Mood" A cycle of romances on verses by G. Longfellow for baritone and piano] Kazan', 1965 - Tomsk, 2004, ZAO «Izdatel'stvo nauchno-tekhnicheskoj literatury»;

5. Budnikov V.V. Tembral'naya montirovka-maskirovka zvukov $\mathrm{v}$ fortepiannoj fakture: sinteticheskij aspekt. [Timbre mount - masking sounds in the piano texture: synthetic aspect] Nauchno-prakticheskij zhurnal «Muzykal'nyj al'manah tomskogo gosudarstvennogo universiteta», 2020, №9; M. 1961

6. Nejgauz G.G. Ob iskusstve fortepiannoj igry. [On the art of piano playing.] 